$2018 \uparrow$ Volume $21 \uparrow$ Issue $3 \uparrow 137-150$

DOI: $10.24425 / 124499$

\title{
Coal sludge and their mixtures as prospective energy resources
}

ABSTRACT: The new legislative provisions, regulating the solid fuel trade in Poland, and the resolutions of provincial assemblies assume, inter alia, a ban on the household use of lignite fuels and solid fuels produced with its use; this also applies to coal sludge, coal flotation concentrates, and mixtures produced with their use. These changes will force the producers of these materials to find new ways and methods of their development, including their modification (mixing with other products or waste) in order to increase their attractiveness for the commercial power industry. The presented paper focuses on the analysis of coal sludge, classified as waste (codes 010412 and 010481 ) or as a by-product in the production of coals of different types. A preliminary analysis aimed at presenting changes in quality parameters and based on the mixtures of hard coal sludge (PG SILESIA) with coal dusts from lignite (pulverized lignite) (LEAG) has been carried out. The analysis of quality parameters of the discussed mixtures included the determination of the calorific value, ash content, volatile matter content, moisture content, heavy metal content ( $\mathrm{Cd}, \mathrm{Tl}, \mathrm{Hg}, \mathrm{Sb}, \mathrm{As}, \mathrm{Pb}$, $\mathrm{Cr}, \mathrm{Co}, \mathrm{Cu}, \mathrm{Mn}, \mathrm{Ni}$, and $\mathrm{W}$ ), and sulfur content. The preliminary analysis has shown that mixing coal sludge with coal dust from lignite and their granulation allows a product with the desired quality and physical parameters to be obtained, which is attractive to the commercial power industry. Compared to coal sludge, granulates made of coal sludge and coal dust from lignite with or without ground dolomite have a higher sulfur content (in the range of 1-1.4\%). However, this is still an acceptable content for solid fuels in the commercial power industry. Compared to the basic coal sludge sample, the observed increase in the content of individual toxic components in the mixture samples is small and it therefore can be concluded that the addition of coal dust from lignite or car-

${ }^{1}$ Mineral and Energy Economy Research Institute, Polish Academy of Sciences, Kraków; e-mail: beatakk@minpan.krakow.pl, jan@min-pan.krakow.pl

${ }^{2}$ EP Coal Trading Poland SA Czechowice-Dziedzice; e-mail: marek.wiencek@epcoaltrading.pl 
bonates has no significant effect on the total content of the individual elements. The calorific value is a key parameter determining the usefulness in the power industry. The size of this parameter for coal sludge in an as received basis is in the range of $9.4-10.6 \mathrm{MJ} / \mathrm{kg}$. In the case of the examined mixtures of coal sludge with coal dust from lignite, the calorific value significantly increases to the range of 14.0-14.5 MJ/kg (as received). The obtained values increase the usefulness in the commercial power industry while, at the same time, the requirements for the combustion of solid fuels are met to a greater extent. A slight decrease in the calorific value is observed in the case of granulation with the addition of $\mathrm{CaO}$ or carbonates. Taking the analyzed parameters into account, it can be concluded that the prepared mixtures can be used in the combustion in units with flue gas desulfurization plants and a nominal thermal power not less than $1 \mathrm{MW}$. At this stage of work no cost analysis was carried out.

KEYWORDS: hard coal mining, coal sludge, coal dust from lignite (pulverized lignite), granulation, quality parameters, calorific value, professional power industry

\section{Introduction}

The Government's bill amending the Act on Fuel Quality Monitoring and Control System and the Act on the National Treasury Administration of 19 March 2018 (http://www.sejm.gov. pl) assumes a number of changes in the Fuel Quality Monitoring and Control System Act of 25 August 2006 (Journal of Laws 2018, item 427). The mentioned bill is focused on the regulation of the fuel market in order to allow consumers to purchase solid fuels meeting the quality requirements for fuels intended for the municipal and household sector. The bill assumes, inter alia, a ban on the household use of lignite fuels and solid fuels produced with its use; this also applies to coal sludge, coal flotation concentrates, and mixtures produced with their use. The adopted resolutions of the following provincial assemblies: the Małopolska, Silesia, Opole, Lower Silesia, Wielkopolska, Łódź, and the Masovian provincial assembly are in line with the mentioned Bill, combating low-stack emissions and thus poor air quality in Poland. As of the beginning of 2018, the Podkarpackie Province has a draft of such a resolution, while the three subsequent Provinces (Lubuskie, Świętokrzyskie and Lubelskie) are considering similar resolutions (Stala-Szlugaj 2018a, 2018b). The ban on the use of low-quality fuels will help to reduce the level of pollutants in the air. Environmental education is an important element contributing to the low-stack emission reduction (Pawul and Sobczyk 2011).

The existing and newly introduced legal provisions, introducing a ban on the trade and combustion of coal sludge, flotation concentrates, lignite and its derivatives, do not exclude or limit the production of these materials during mining activities. The current annual sales of coal sludge and flotation concentrates produced by hard coal mines to the municipal sector is 1-1.5 million Mg (https://www.rp.pl/Wegiel/). The mentioned ban will force the manufacturers to find new ways and methods for their use in order to reach every possible client niche. The 
discussed products are an inherent by-product of the extraction and processing of hard coal. In the discussed case, coal sludge, flotation concentrates, and lignite are not considered as waste. However, generally worse quality parameters, combined with wrong combustion methods and technologies (manually operated boilers), are the reasons why the use of these fuels in households (unlike in the case of the commercial power industry) can cause smog.

The new legislative provisions, regulating the solid fuel trade in Poland, will affect the current functioning of enterprises operating in this industry (mines); they will also force the manufacturers of these materials to find new ways and methods for their use. One possible solution may be storage, but it involves a potential threat to the environment and environmental charges. Therefore, there is a need to look for new ways to use coal sludge, and a possible solution is to use them in various mixtures or in reclamation of degraded areas and in the sealing of landfills (Klojzy-Karczmarczyk et al. 2016; Klojzy-Karczmarczyk and Mazurek 2016). Coal sludge are and will continue to be mining products with a specific energy value. The problem of coal sludge a problem of coal fuel with a high content of water, ash, often a low calorific value, and poor mechanical parameters hindering transportation. The authors of the article asked themselves how to increase the attractiveness of coal sludge as a fuel for the professional power industry. The essence of the solution may be to increase the calorific value of this material by an admixture of other materials, including waste materials.

\section{Research subject}

The paper discusses the issue of searching for new applications for coal sludge (coal slurry) from hard coal mining. Coal sludge is a waste resulting from the processing of coal (code 0104 12 - tailings and other wastes from washing and cleaning of minerals other than those mentioned in 010407 and 010411 or 010481 - waste from coal flotation other than those mentioned in 010480 ). However, coal sludge are often not classified as waste and constitute a by-product in the production of hard coal of different types. Regardless of statutory restrictions, the main recipient of coal sludge produced in mines is the professional power industry, technologically and logistically prepared for their combustion without harm to the environment (air quality). Due to the expected withdrawal from the municipal market, the amount of coal sludge offered by mines for this group is likely to increase. In addition, when it comes to lignite and its derivatives, the use and sale in the retail market has been limited by the Government's bill amending the Act on Fuel Quality Monitoring and Control System and the Act on the National Treasury Administration of 19 March 2018 and provincial assemblies resolution. The preliminary analysis presented in the current paper was aimed at presenting changes in quality parameters based on the comparison between mixtures of hard coal sludge with coal dusts from lignite and the starting material that is coal sludge.

According to U. Lorenz and U. Ozga-Blaschke (2005), the current knowledge and technology allow us to efficiently use coal sludge in the energy industry; the use value of this energy 
source is determined by the potential recipients. The quality parameters of coal sludge (the calorific value, gross calorific value) have been widely discussed in the literature; the scale of the problem, the need for development, and the use of coal sludge for energy production are well described (e.g. Sobko et al 2011; Baic and Blaschke 2012; Baic et al. 2012a, 2012b; Baic 2013). Coal sludge are not only produced in a continuous manner during mining activities but are also stored, in millions of $\mathrm{Mg}$, in coal sludge ponds. The inventory carried out by I. Baic, W. Sobko, and M. Łukowska (Baic et al. 2012a) showed that more than 16.5 million Mg of coal sludge are deposited in Poland, which, directly or through the use of appropriate processing technologies, may be a valuable raw material for the professional power industry.

Based on the selected data (including Grudziński 2005; Hycnar et al. 2005; Jelonek et al. 2010; 2016; Lutyński and Szpyrka 2010; 2011, Hycnar et al. 2013; Klojzy-Karczmarczyk and Mazurek 2017), it can be concluded that coal sludge are generally characterized by inferior quality parameters when compared to coal produced in mines. In particular, this applies to the ash content, which is between 24 and 50\%, and the moisture content between 31 and $46 \%$. In the case of sulfur content, the values determined for coal sludge range from 0.5 to $1.8 \%$ and are similar to the sulfur content in other coals (or even slightly smaller). Regarding the energy parameters it can be concluded that the calorific value of coal sludge is within the limits from 6 to $17 \mathrm{MJ} / \mathrm{kg}$. At the same time, a number of actions (e.g. reducing the moisture, granulation, grain classification) contributing to an increase in the calorific value of up to $25 \mathrm{MJ} / \mathrm{kg}$ and thus increase the energy efficiency of their combustion has been performed (Hycnar et al. 2013).

\section{Preparation of samples for preliminary analysis}

The authors raised the question of how to increase the attractiveness of coal sludge from hard coal mining as a fuel for the professional power industry. Based on consultations with representatives of the EP Coal Trading Polska S.A., a company belonging to the EPH Group, the idea of enriching coal sludge with coal dust from lignite (hazardous material) in order to improve their energy parameters has been brought up. The discussed group owns hard coal mines (PG SILESIA), where coal sludge subjected to the analysis are produced and lignite mines (Germany) and produces coal dust from lignite (pulverized lignite) (LEAG-Germany), which was used in the enrichment of coal sludge for the presented work.

Preliminary tests were carried out in order to determine the usefulness of the coal sludge enrichment carried out by granulating them with coal dust from lignite while improving their transport capabilities. The planned studies will examine the possibility of obtaining the product with the proper quality and physical parameters and improved energy parameters based on mixing coal sludge with coal dust and their granulation. The resulting product may be of interest to the professional coal-based power industry, which would undoubtedly translate into its commercial attractiveness and would become, although in some part, a new way of managing coal sludge and 
coal dust from lignite. The basic material samples subjected to the analysis included coal sludge, coal dust and mixtures with binding material. $\mathrm{CaO}$ is commonly used as a binding material in the granulation processes. However, in this case, the binder was replaced with another waste material, namely ground calcium and magnesium carbonate (sifting from crushing dolomite with grain size of $0-4 \mathrm{~mm}$ ). The conditions and results of the granulation process are discussed in a separate work by J. Feliks, B. Klojzy-Karczmarczyk and M. Wiencek (Feliks et al. 2018). In addition, for comparison purposes, a mixture of coal sludge with soot was prepared. The tested samples are described and summarized in Table 1. The individual substrates were mixed in an air-dry basis, in accordance with the percentage values in the table. The quality parameters of the samples were analyzed after the granulation process.

At this stage of work no cost analysis was carried out by the authors. This is due to the fact that the research results will have a huge impact on both the commercial attractiveness of the "new" product and the mentioned analysis.

TABLE 1 . The summary of samples subjected to preliminary laboratory tests

TABELA 1. Zestawienie próbek przeznaczonych do wstępnych badań laboratoryjnych

\begin{tabular}{|c|c|}
\hline Sample number and name & $\begin{array}{l}\text { The assumed percentage composition of substrates in individual } \\
\text { mixtures for granulation and the analysis of quality parameters }\end{array}$ \\
\hline $\begin{array}{l}\text { Sample No. } 1 \\
\text { coal sludge }+ \text { dust }\end{array}$ & Coal sludge $(50 \%)+$ coal dust from lignite $(50 \%)$ \\
\hline $\begin{array}{c}\text { Sample No. } 2 \\
\text { coal sludge }+ \text { soot }+ \text { carbonate }\end{array}$ & $\begin{array}{c}\text { Coal sludge }(45 \%)+\text { soot }(45 \%) \\
+ \text { sifting from dolomite crushing }(10 \%)\end{array}$ \\
\hline $\begin{array}{c}\text { Sample No. } 3 \\
\text { coal sludge }+ \text { dust }+ \text { carbonate }\end{array}$ & $\begin{array}{l}\text { Coal sludge }(45 \%)+\text { coal dust from lignite }(45 \%) \\
+ \text { sifting from dolomite crushing }(10 \%)\end{array}$ \\
\hline $\begin{array}{l}\text { Sample No. } 4 \\
\text { carbonate }\end{array}$ & Sifting from crushing dolomite with grain size of $0-4 \mathrm{~mm}$ \\
\hline $\begin{array}{l}\text { Sample No. } 5 \\
\text { coal dust }\end{array}$ & Coal dust from lignite, hazardous material \\
\hline $\begin{array}{l}\text { Sample No. } 6 \\
\text { coal sludge }\end{array}$ & Coal sludge after dewatering on filter presses \\
\hline $\begin{array}{c}\text { Sample No. } 7 \\
\text { coal sludge }+\mathrm{CaO}\end{array}$ & Coal sludge $(97 \%)+\mathrm{CaO}(3 \%)$ \\
\hline
\end{tabular}

Material origin: Coal sludge from hard coal mining - PG SILESIA.

Coal dust from lignite (pulverized lignite) - LEAG - Germany.

The substrates were mixed in an air-dry condition. 


\section{The applied methodology and the analysis of test results}

The assumed percentage composition of substrates in individual mixtures intended for the granulation process and analysis of quality parameters (calorific value, ash content, volatile matter content, total moisture content, heavy metal content, and sulfur content) is presented in Table 1. The test results and the methodology are presented in Tables 2 and 3. The calorific value, ash, volatile matter and sulfur content (Table 3 ) were determined on an as received basis and then converted to a dry basis. On the other hand, heavy metal and sulfur contents were determined using the ICP OES method, and expressed in $\mathrm{mg} / \mathrm{kg}$ of dry matter, after the substrates were digested in a microwave mineralizer. Only a mercury content analysis was conducted with the AAS method using an AMA 254 spectrometer for mercury determination. The mercury content in individual samples was determined in air-dry basis $\left(\mathrm{Hg}^{\mathrm{a}}\right)$. The moisture content of the samples was determined in the range of $1.5-2 \%$. With such low moisture content, it can be assumed that the mercury content in air-dry basis is similar to the mercury content in dry basis $\left(\mathrm{Hg}^{\mathrm{d}}\right)$. The quality parameters were analyzed for the samples subjected to the granulation process in a vibratory granulator (Feliks et al. 2018).

As of today in Poland, there are no emission limits for heavy metals emitted from coal-fired power plants. In addition, there are also no legal regulations regarding the content of these elements in the combusted fuels. Emission limits for heavy metals were determined only for the combustion and co-combustion of municipal waste (Regulation 2018). The discussed document determined, among others, emission standards for $\mathrm{Cd}, \mathrm{Tl}, \mathrm{Hg}, \mathrm{Sb}, \mathrm{As}, \mathrm{Pb}, \mathrm{Cr}, \mathrm{Co}, \mathrm{Cu}, \mathrm{Mn}, \mathrm{Ni}$, and W. Emission standards were introduced based on new BAT conclusions (BAT-LCP 2016) for large facilities under the Industrial Emission Directive (Directive 2010/75 / EU). In Poland, the mentioned Directive was implemented by the Act of 11 July 2014 on the amendment of Environmental Protection Act. (Journal of Laws, 2014, item 1101). The regulations introduce, among others, tighter emission standards for $\mathrm{CO}_{2}, \mathrm{NO}_{\mathrm{x}}, \mathrm{SO}_{3}$ and new emission limits for mercury in flue gases of solid fuels. Based on literature data (Bielowicz 2013; Kosa and Kicińska 2016; Makowska et al. 2017) 12 toxic elements and sulphur were selected for the analysis of the basic material and mixtures after the granulation process. The content of the individual elements is presented in Table 2 .

The obtained results of the analysis of granulated mixtures of coal sludge, dust and soot were compared with the results obtained for basic samples, i.e. coal sludge (sample No. 6). The analysis has shown that, compared to coal sludge (a sulfur content of $0.5 \%$ ), the coal dust from lignite has a much higher total sulfur content of up to $1.44 \%$, which undoubtedly contributes to an increase of this parameter in the analyzed mixture samples. Granulates made of coal sludge, coal dust, and soot with or without the addition of ground dolomite have a sulfur content of $1 \%$. However, despite the increase in value, this is still an acceptable content for solid fuels. In the case of coal dusts and carbonates, higher copper and manganese contents have been confirmed, respectively. However, given the percentage of individual substrates used in the granulated mixture samples, 
TABLE 2. The content of the selected toxic elements in samples subjected to preliminary laboratory tests

TABELA 2. Zestawienie zawartości wybranych pierwiastków toksycznych w próbkach przeznaczonych do wstępnych badań laboratoryjnych

\begin{tabular}{|l|c|c|c|c|c|c|c|}
\hline \multirow{2}{*}{ Marking } & \multicolumn{7}{|c|}{ Samples } \\
\cline { 2 - 8 } & $\begin{array}{c}1 \\
\text { coal sludge } \\
+ \text { dust } \\
\text { coal sludge } \\
+ \text { soot + } \\
\text { carbonate }\end{array}$ & $\begin{array}{c}3 \\
\text { coal sludge } \\
+ \text { dust + } \\
\text { carbonate }\end{array}$ & $\begin{array}{c}4 \\
\text { carbonate }\end{array}$ & $\begin{array}{c}5 \\
\text { coal dust }\end{array}$ & $\begin{array}{c}6 \\
\text { coal sludge }\end{array}$ & $\begin{array}{c}7 \\
\text { coal sludge } \\
+ \text { CaO }\end{array}$ \\
\hline $\mathrm{S}[\%]$ & 1.01 & 1.02 & 0.93 & 0.03 & 1.44 & 0.53 & 0.48 \\
\hline $\mathrm{Hg}[\mathrm{mg} / \mathrm{kg}]^{*}$ & 0.1150 & 0.0982 & 0.1311 & 0.0088 & 0.1108 & 0.1318 & 0.1395 \\
\hline $\mathrm{As}[\mathrm{mg} / \mathrm{kg}]$ & 8.23 & 8.94 & 12.45 & 2.77 & 3.76 & 10.80 & 15.12 \\
\hline $\mathrm{Cd}[\mathrm{mg} / \mathrm{kg}]$ & 0.30 & 1.14 & 0.09 & 0.77 & 0.01 & 0.07 & 1.06 \\
\hline $\mathrm{Cr}[\mathrm{mg} / \mathrm{kg}]$ & 41.17 & 40.45 & 62.88 & 3.18 & 9.09 & 63.78 & 53.58 \\
\hline $\mathrm{Co}[\mathrm{mg} / \mathrm{kg}]$ & 8.35 & 72.17 & 13.40 & 0.35 & 0.69 & 18.11 & 14.21 \\
\hline $\mathrm{Cu}[\mathrm{mg} / \mathrm{kg}]$ & 29.10 & 87.15 & 36.07 & 4.16 & 41.98 & 40.27 & 33.56 \\
\hline $\mathrm{Mn}[\mathrm{mg} / \mathrm{kg}]$ & 350.88 & 266.96 & 187.51 & 1600.38 & 81.66 & 176.00 & 190.23 \\
\hline $\mathrm{Ni}[\mathrm{mg} / \mathrm{kg}]$ & 22.11 & 24.44 & 36.94 & 2.37 & 2.67 & 53.53 & 36.30 \\
\hline $\mathrm{Pb}[\mathrm{mg} / \mathrm{kg}]$ & 27.86 & 41.19 & 21.94 & 83.08 & 1.33 & 35.66 & 70.78 \\
\hline $\mathrm{Sb}[\mathrm{mg} / \mathrm{kg}]$ & no & no & no & no & no & no & no \\
\hline $\mathrm{Tl}[\mathrm{mg} / \mathrm{kg}]$ & 0.45 & 0.57 & 0.63 & 0.29 & 0.01 & 0.45 & 0.64 \\
\hline $\mathrm{W}[\mathrm{mg} / \mathrm{kg}]$ & 0.06 & 0.05 & 0.05 & 0.03 & 0.32 & 0.09 & 0.12 \\
\hline
\end{tabular}

The tests were performed using an ICP OES Optima 7000 DV method after the substrates were digested in a microwave mineralizator.

* Analysis performed in an air-dry basis (sample moisture of 1.5-2\%) with the AAS method using an AMA 254 spectrometer.

The increase in value with respect to sample No. 6 was highlighted.

no significant increase in the content of the analyzed components has been observed. Compared to the basic coal sludge sample, the observed increase in the content of individual toxic components in the mixture samples is limited and it can therefore be concluded that the addition of coal dust or carbonates has no significant effect on the total content of the individual elements. A 2-fold increase in the content has been observed only in the case of sulfur.

The quality requirements for solid fuels are specified in the draft of the regulation of the Minister of Energy of 27 January 2017 on the Quality Requirements for Solid Fuels (https:// legislacja.rcl.gov.pl). However, the document is not yet in force. Nevertheless, for comparative purposes and due to the lack of other information, it is possible to combine the obtained results with the values set out in the discussed draft. In particular, the quality requirements for ash content, total sulfur content, calorific value, and total moisture in solid fuels were compared (the draft regulation appendix - Tables 3 to 11). The mentioned quality parameters for the analyzed samples are summarized in Table 3. 
The moisture content is an important indicator of fuel quality and has an impact on the technological aspects of the combustion process. The total moisture content $\left(\mathrm{W}^{\mathrm{r}}\right)$ for the granulated mixtures of coal sludge and coal dust is in the range of 5.9-7.9\%. These values meet the requirements for coal sludge used as solid fuels for combustion in various installations. The ash content $\left(\mathrm{A}^{\mathrm{r}}\right)$ in the mixtures of coal sludge with dust is in the range of 38.2-38.6\%. Based on these values, just like in the case of coal sludge samples (48.6-51.7\%), it can be concluded that the discussed fuel meets the requirements set for solid fuels designed for the combustion in units with flue gas desulfurization plants and a nominal thermal power not less than $1 \mathrm{MW}$. The total sulfur content $\left(\mathrm{S}_{\text {tot }}{ }^{r}\right)$ in the analyzed samples of mixtures of coal sludge and coal dust is in the range of $1.28-1.41 \%$. However, it should be noted that lower sulfur contents were obtained using ICP OES method (Table 2). When compared to coal sludge samples, a significant (threefold) increase in the content of this element can be observed. When it comes to hard coal mixtures with coal sludge and flotation concentrates, the draft regulation under consideration assumes maximum values for total sulfur content at the level of $1.00-1.30 \%$. In the case of mixtures prepared during the analysis, the sulfur content slightly exceeds the mentioned values. These requirements are only met for solid fuels for combustion in units with desulfurization plants and a nominal thermal input not less than $1 \mathrm{MW}$, as in the case of the previously analyzed parameter, namely ash content.

TABLE 3 . The quality parameters of samples for preliminary laboratory analysis

TABELA 3. Parametry jakościowe dla próbek przeznaczonych do wstępnych badań laboratoryjnych

\begin{tabular}{|c|c|c|c|c|c|c|}
\hline \multirow[b]{2}{*}{ Marking } & \multirow[b]{2}{*}{ Standard } & \multicolumn{5}{|c|}{ Samples } \\
\hline & & $\begin{array}{c}1 \\
\text { coal slud- } \\
\text { ge }+ \\
+ \text { dust }\end{array}$ & $\begin{array}{c}2 \\
\text { coal } \\
\text { sludge } \\
+ \text { soot }+ \\
\text { carbonate }\end{array}$ & $\begin{array}{c}3 \\
\text { coal } \\
\text { sludge } \\
+ \text { dust + } \\
\text { carbonate }\end{array}$ & $\begin{array}{c}6 \\
\text { coal } \\
\text { sludge }\end{array}$ & $\begin{array}{c}7 \\
\text { coal } \\
\text { sludge }+ \\
\mathrm{CaO}\end{array}$ \\
\hline The calorific value $\mathrm{Q}_{\mathrm{i}}^{\mathrm{r}}[\mathrm{kJ} / \mathrm{kg}]$ & PN-81/G-04513 & 14532 & 16551 & 14052 & 10622 & 9366 \\
\hline The calorific value $\mathrm{Q}_{\mathrm{i}}{ }^{\mathrm{d}}[\mathrm{kJ} / \mathrm{kg}]$ & dry basis * & 15779 & 17028 & 14933 & 11634 & 10993 \\
\hline $\begin{array}{l}\text { The volatile matter content } \\
\mathrm{V}^{\text {daf }}[\%]\end{array}$ & $\begin{array}{l}\text { PN-G-04516: } \\
1998\end{array}$ & 55,06 & 24,32 & 58,17 & 43,77 & 45.99 \\
\hline The ash content $\mathrm{A}^{\mathrm{r}}[\%]$ & $\begin{array}{l}\text { PN-80/G-04512 } \\
\quad+\text { Az1:2002 }\end{array}$ & 38,2 & 40,2 & 38,6 & 51,7 & 48.6 \\
\hline The total sulfur content $\mathrm{S}_{\text {tot }}{ }^{\mathrm{r}}[\%]$ & $\begin{array}{l}\text { PN-G-04584: } \\
2001\end{array}$ & 1,41 & 1,42 & 1,28 & 0,63 & 0.57 \\
\hline The total sulfur content $\mathrm{S}_{\text {tot }}{ }^{\mathrm{r}}[\%]$ & dry basis * & 1,53 & 1,46 & 1,36 & 0,69 & 0.67 \\
\hline $\begin{array}{l}\text { The total moisture content } \mathrm{W}^{\mathrm{r}} \\
{[\%]}\end{array}$ & $\begin{array}{l}\text { PN-80/G-04511 } \\
\quad(p .2 .3 .1)\end{array}$ & 7,9 & 2,8 & 5,9 & 8,7 & 14,8 \\
\hline
\end{tabular}

$\mathrm{r}$ - as received, $\mathrm{d}-$ dry basis, daf - dry and ash free basis.

The tests were performed by the chemical laboratory of the PG SILESIA Sp. z o.o.

* Converted to a dry basis: $\frac{1}{1-W^{r}}$. 
The most important parameter determining the usefulness of waste or by-products for energy purposes is the calorific value (gross calorific value). The calorific value of coal sludge (as received) is in the range of 9.4-10.6 MJ/kg and increases to $11.0-11.6 \mathrm{MJ} / \mathrm{kg}$ (recalculated to dry basis), with a slight decrease in calorific value in the case of granulation with the addition of $\mathrm{CaO}$. When it comes to the minimum values set in the draft regulation, the mentioned coal sludge meet the minimum values only in the case of units with flue gas desulfurization plants and a nominal thermal power not less than $1 \mathrm{MW}$. In the case of examined mixtures of coal sludge with coal dust from lignite, the calorific value significantly increases (Fig. 1) to the range of $14.0-14.5 \mathrm{MJ} / \mathrm{kg}$ (as received) and 14.9-15.8 MJ/kg (dry basis). A slight decrease in this parameter can be observed in the case of granulation with the addition of carbonates. The obtained values increase the possibilities of their application in the power industry and largely meet the requirements for the combustion of solid fuels (hard coal, briquettes, and pellets containing at least $90 \%$ hard coal, coal sludge and flotation concentrates) in units with flue gas desulfurization plants and a nominal thermal power not less than $1 \mathrm{MW}$. For comparison purposes, the calorific value of hard coal is 24.5-33.8 MJ/kg and 7-21 MJ/kg for lignite (http://www.instalacjebudowlane.pl).

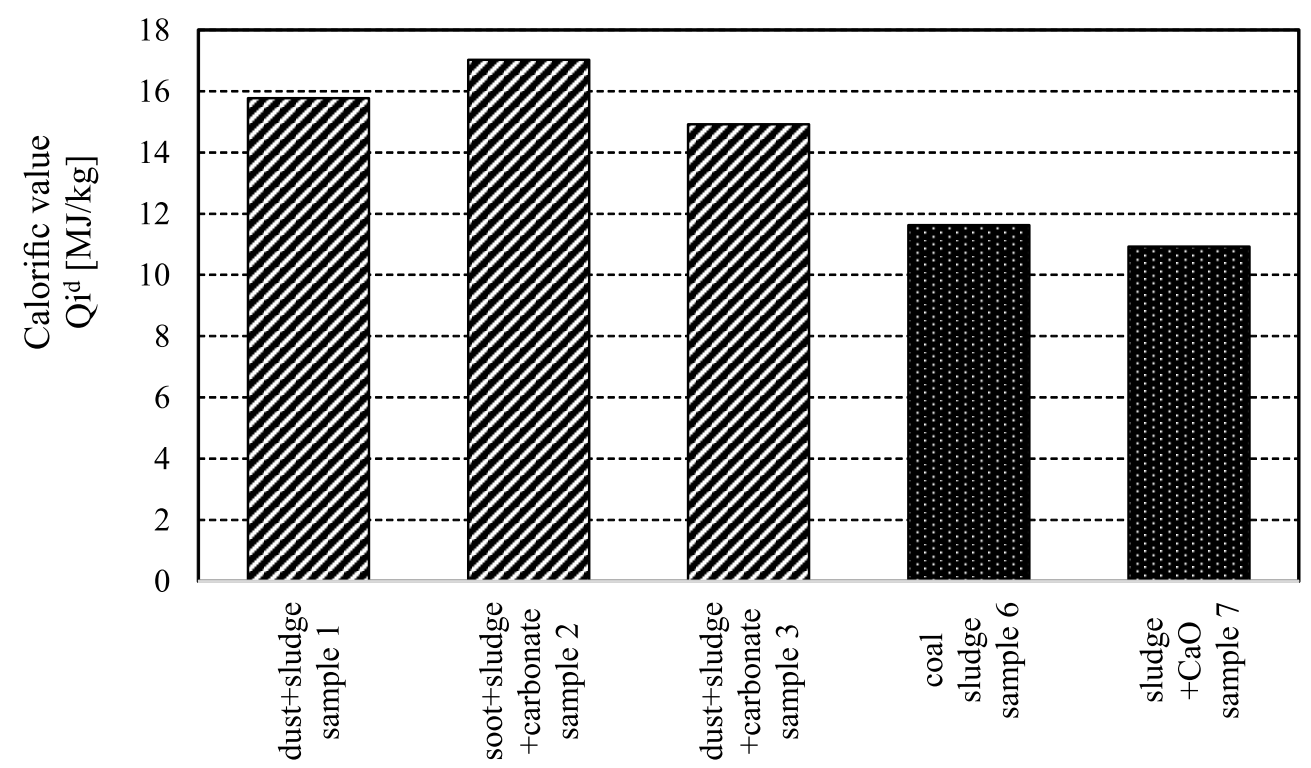

Fig. 1. The calorific value of coal sludge and the analyzed granulated mixtures of coal sludge and coal dust from lignite

Rys. 1. Zestawienie wartości opałowej analizowanych zgranulowanych mieszanek mułów węglowych z pyłami węglowymi w odniesieniu do samych mułów węglowych 


\section{Conclusions}

Coal sludge (coal slurry), usually with a low calorific value, are an inherent by-product of hard coal production. They are classified as a waste (codes 010412 and 010481 ) or a by-product of raw material production with a limited energy importance. The aim of the study was to carry out research to find a way to increase the usefulness of coal sludge as a fuel for professional power, by raising the calorific value of this material and improve its transport properties.

A preliminary analysis aimed at presenting changes in quality parameters and based on the mixtures of hard coal sludge (PG SILESIA) with coal dusts from lignite (pulverizing coal) (LEAG) has been carried out. There is a need to look for new solutions for the management of both materials due to the expected withdrawal from the municipal market. Preliminary research has shown that mixing coal sludge with coal dust and their granulation allows a product with the desired quality and physical parameters to be obtained, which is attractive to the commercial power industry.

It has been shown that, compared to coal sludge, granulates made of coal sludge and coal dust with or without ground dolomite are characterized by an increase in sulfur content to $1-1.4 \%$. Still, in some cases, this is the permissible value for solid fuels in the power industry. When compared to the basic coal sludge sample, the observed increase in the content of individual toxic components in the mixture samples is small and it can therefore be concluded that the addition of coal dust or carbonates has no significant effect on the total content of individual elements.

The calorific value of coal sludge (as received) is in the range of 9.4-10.6 MJ/kg (11.0$-11.6 \mathrm{MJ} / \mathrm{kg}$ in dry basis). In the case of examined mixtures of coal sludge with coal dust from lignite, the calorific value significantly increases to the range of $14.0-14.5 \mathrm{MJ} / \mathrm{kg}$ (as received) and 14.9-15.8 MJ/kg (dry basis). The obtained values increase the usefulness of coal sludge mixtures in the commercial power industry and, as a consequence, the requirements for the combustion of solid fuels are met to a greater extent. A slight decrease in the calorific value is observed in the case of granulation with the addition of $\mathrm{CaO}$ or carbonates. Taking the calorific value of the analyzed granular mixtures, total moisture, sulfur content, and ash content into account, it can be concluded that the prepared mixtures can be used in solid fuel combustion units with flue gas desulfurization plants and a nominal thermal power not less than $1 \mathrm{MW}$.

At this stage of the work no cost analysis was carried out by the authors. The mentioned analysis, however, should be carried out in another paper. The percentage composition of individual components in the proposed granulates is only a preliminary assumption. The next step may be the change of substrates and the determination of optimal content of individual components and their impact on the quality and physical parameters of the tested product. Based on the preliminary research it can be concluded that the topic is promising and there is a need for further studies.

The research was performed within the framework of the statutory work of the of the Mineral and Energy Economy Research Institute of the Polish Academy of Sciences. 


\section{References}

[Online] http://www.instalacjebudowlane.pl - The energy value of coal, gas, oil and other fuels (Wartość energetyczna węgla, gazu, oleju i innych paliw) (in Polish) [Accessed: 2018-07-23].

[Online] http://www.sejm.gov.pl - The Government's bill amending the Act on the fuel quality monitoring and control system and the Act on the National Treasury Administration of 19 March 2018, form No. 2377 [Accessed: 2018-07-23].

[Online] https://legislacja.rcl.gov.pl - A draft of the Regulation of the Minister of Energy of 27 January 2017 on the quality requirements for solid fuels [Accessed: 2018-07-23].

[Online] https://www.rp.pl/Wegiel/ - Even more expensive Polish coal (Jeszcze droższy polski weggiel) (in Polish) [Accessed: 2018-08-12].

BAIC et al. 2012a - BAIC, I., SoBKO, W. and ŁUKOWSKA, M. 2012. Inventory and in situ estimates of coal sludge deposits (Inwentaryzacja szacunkowa i in-situ depozytów mułów węglowych). Polityka Energetyczna - Energy Policy Journal Vol. 15, Iss. 3, pp. 221-229 (in Polish).

BAIC et al. 2012b - BAIC, I., LUTYŃSKI, A. and LUTYŃSKI, M. 2012. Energetic potential of coal slurries (Potencjat energetyczny zdeponowanych mułów węglowych). Polityka Energetyczna - Energy Policy Journal Vol. 15, Iss. 3, pp. 259-271 (in Polish).

BAIC, I. 2013 - Analysis of the Chemical, Physical and Energetic Parameters of Coal Sludge Deposits Inventoried in the Silesian Province (Analiza parametrów chemicznych, fizycznych i energetycznych depozytów mułów węglowych zinwentaryzowanych na terenie województwa śląskiego). Rocznik Ochrony Środowiska (Annual Set The Environment Protection) Vol. 15, pp. 1511-1524 (in Polish).

Baic, I. and BlaschKe, W. 2012. The issue of coal sludge deposits in Poland (Problematyka depozytów mułów węglowych w Polsce). Polityka Energetyczna - Energy Policy Journal Vol. 15, Iss. 3, pp. 211 -219 (in Polish).

BAT-LCP 2016 - Best Available Techiques (BAT) Reference Document for Large Combustion Plants, Final Draft, June 2016, European Commission.

BIELOwICZ, B. 2013. Selected harmful elements in Polish lignite (Występowanie wybranych pierwiastków szkodliwych w polskim węglu brunatnym). Gospodarka Surowcami Mineralnymi-Mineral Resources Management Vol. 29, Iss. 3, pp. 47-59 (in Polish).

Directive 2010/75/EU of the European Parliament and of the Council of 24 November 2010 on industrial emissions (integrated pollution prevention and control).

Journal of Laws, 2018, item 427 - Fuel Quality Monitoring and Control System Act of 25 August 2006.

Journal of Laws, 2014, item 1101 - The Act of 11 July 2014 on the amendment of Geological and Mining Law and of certain other Acts.

FeliKs J. et al. 2018 - FeliKs, J., KLOJZY-KARCZMARCZYK, B. and WiENCEK, M. 2018. Granulating of coal sludge and their mixtures to improve transport properties (Granulowanie mułów weglowych $i$ ich mieszanek w celu poprawy właściwości transportowych). Zeszyty Naukowe Instytutu Gospodarki Surowcami Mineralnymi i Energia PAN, in print (in Polish).

GRUDZIŃSKI, Z. 2005. Comparative analysis of quality of coal sludge from the current production and dumped in settling ponds (Analiza porównawcza jakości mułów węgla kamiennego pochodzacych z bieżacej produkcji i zdeponowanych w osadnikach ziemnych). [In:] Kompleksowe i Szczegótowe Problemy Inżynierii Środowiska (Complex and Detailed Problems of Environmental Engineering), Conference materials, Koszalin, pp. 671-679 (in Polish).

HYCNAR et al. 2005 - HYCNAR, J.J., FOLTYN, R., OlKuSKI, T. and BlaschKe, S.A. 2005. Utilisation Of Fine-Grained Wastes From Hard Coal Production And Preparation In Power Generation Sector (Kierunki energetycznego wykorzystania drobnoziarnistych odpadów z wydobycia $i$ wzbogacania wegla kamiennego). Conference materials of the VII National Scientific Conference Kompleksowe 
i Szczegółowe Problemy Inżynierii Środowiska (Complex and Detailed Problems of Environmental Engineering), Koszalin, pp. 639-650 (in Polish).

HyCNAR et al. 2013 - HyCNAR, J.J., FraŚ, A., PrZystaŚ, R. and Foltyn, R. 2013. Current state and perspectives of quality improvement of coal slimes for power generation (Stan i perspektywy podwyższenia jakości mułów węglowych dla energetyki). Conference materials of the XXVII edition of the conference Zagadnienia surowców energetycznych i energii w gospodarce krajowej (Issues of Energy Resources and Energy in the Domestic Economy), pp. 61-74 (in Polish).

JELONEK et al. 2010 - JelONEK, I., MiRKOWSKI, Z. and IWANEK, P. 2010. Physical-chemical properties of coal slurries in aspect of their use on example of PKE S.A. selected object (Analiza własności fizykochemicznych i petrograficznych mułów węglowych w aspekcie ich wykorzystania jako paliwa na przykładzie wybranego obiektu PKE S.A.). Przegląd Górniczy Vol. 66, No.10, pp. 156-160 (in Polish).

JELONEK et al. 2016 - JELONEK, I, MIRKOWSKI, Z. and JELONEK, Z. 2016. The characteristics of floto-concentrate and coal slurries used in central heating stoves as well as the by-products of their combustion (Cechy flotokoncentratów oraz mułów węglowych stosowanych w piecach centralnego ogrzewania oraz charakterystyka produktów ubocznych powstatych w wyniku ich spalania). Zeszyty Naukowe Instytutu Gospodarki Surowcami Mineralnymi i Energia PAN No. 96, pp. 91-104 (in Polish).

Klojzy-KarczmarczyK, B. and MazureK, J. 2017. Proposals to extend actions to the management of waste rock from hard coal mining (Propozycje rozszerzenia dziatań celem zagospodarowania materiatów odpadowych z górnictwa węgla kamiennego). Zeszyty Naukowe Instytutu Gospodarki Surowcami Mineralnymi i Energia PAN No. 98, pp. 151-165 (in Polish).

KloJZY-KARCZMARCZYK et al. 2016 - KloJZY-KARCZMARCZYK, B., MAZUREK, J. and PAW, K. 2016. Possibilities of Utilization of Aggregates and Extractive Waste from Hard Coal Mining at Janina Mine in the Process of Reclamation of Open-pit Mines (Możliwości zagospodarowania kruszyw i odpadów wydobywczych górnictwa węgla kamiennego ZG Janina w procesach rekultywacji wyrobisk odkrywkowych). Gospodarka Surowcami Mineralnymi - Mineral Resources Management Vol. 32, Iss. 3, pp. 111-134 (in Polish).

KosA, B. and KicińSKA, A. 2016. Coal from the waste disposal site of the Siersza mine (Trzebinia, Poland) and its properties as a possible alternative fuel, E3S Web of Conferences, SEED, 00039.

LORENZ, U. and OZGA-BLASCHKE U. 2005. Hard coal - energetic product or waste (Muły wegla kamiennego - produkt energetyczny czy odpad). Conference materials of the VII National Scientific Conference Kompleksowe i Szczegółowe Problemy Inżynierii Środowiska (Complex and Detailed Problems of Environmental Engineering), Koszalin, pp. 681-682 (in Polish).

LUTYŃSKI, A. and SZPYRKA, J. 2010. Disposal of fine tailings from hard coal beneficiation (Zagospodarowanie drobnoziarnistych odpadów ze wzbogacania węgla kamiennego). AGH Journal of Mining and Geoengineering Vol. 34, Iss. 4/1, pp. 155-164 (in Polish).

LUTYŃSKI, A. and SZPYRKA, J. 2011. Quality assessment of hard coal slurries deposited in impoundments (Analiza jakości mułów węgla kamiennego zdeponowanych w osadnikach naziemnych). Mining and Geology Vol. 6 (2), pp. 121-129 (in Polish).

Makowska et al. 2017 - MakowsKa, D., Wierońska, F., Dziok, T. and StrugaŁa, A. 2017. Ecotoxic elements emission from the combustion of solid fuels due to legal regulations (Emisja pierwiastków ekotoksycznych z procesów spalania paliw statych $w$ świetle regulacji prawnych). Polityka Energetyczna - Energy Policy Journal Vol. 20, Iss. 4, pp. 89-102 (in Polish).

PAWUL, and SOBCZYK, 2011. Ecological Education in Waste Management as a Tool for The Implementation of Sustainable Development (Edukacja ekologiczna w zakresie gospodarki odpadami jako narzędzie realizacji zrównoważonego rozwoju). Problems of sustainable development Vol. 6, No. 2, pp. 147-156 (in Polish). 
Regulation 2018 - Regulation of the Minister of the Environment of March 1, 2018 on emission standards for certain types of installations, fuel combustion sources and appliances for waste incineration or co-incineration, Journal of Laws, 2018, item 680.

SobKo et al. 2011 - SoBKo, W., BAIC, I. and BlASCHKE, W. 2011. Deposits of coal sludge - inventory and quantitative identification (Depozyty mułów węglowych - inwentaryzacja i identyfikacja ilościowa). Rocznik Ochrony Środowiska (Annual Set The Environment Protection) Vol. 13, pp. 1405-1413 (in Polish).

StAla-SzlugaJ, K. 2018a. Anti-smog resolutions in Poland and their impact on hard coal consumption in households (Uchwaly antysmogowe w Polsce a ich oddzialywanie na zużycie wegla kamiennego w gospodarstwach domowych). Inżyieria Mineralna - Journal of the Polish Mineral Engineering Society No. 2; in print (in Polish).

Stala-Szlugaj, K. 2018b. Hard coal demand for households in Poland vs. anti-smog law. Archives of Mining Sciences Vol. 63, Iss. 3, pp. 701-711.

\section{Muły węglowe i ich mieszanki jako perspektywiczne surowce energetyczne}

\section{Streszczenie}

Wprowadzane nowe przepisy legislacyjne, regulujące w naszym kraju obrót paliwami stałymi oraz uchwały sejmików poszczególnych województw zakładają między innymi zakaz stosowania w gospodarstwach domowych jako paliwa węgla brunatnego oraz paliw stałych produkowanych z jego wykorzystaniem, a także mułów i flotokoncentratów węglowych oraz mieszanek produkowanych z ich wykorzystaniem. Zmiany te będą wymuszały na producentach tych materiałów znalezienie nowych sposobów i metod ich zagospodarowania, m.in. poprzez modyfikację (mieszanie z innymi produktami lub odpadami) w celu wzrostu ich atrakcyjności dla energetyki zawodowej. Praca obejmuje swoją analizą muły węglowe, klasyfikowane jako odpad o kodzie 010412 i 010481 lub jako produkt uboczny w produkcji węgla kamiennego o zróżnicowanym znaczeniu energetycznym. Podjęto wstępne badania pozwalające na wykazanie zmian ich parametrów jakościowych poprzez sporządzanie mieszanek na bazie mułów węglowych węgla kamiennego (PG SILESIA) z pyłami węglowymi z węgla brunatnego (LEAG). W ramach analizy parametrów jakościowych sporządzonych mieszanek badano wartość opałową, zawartość popiołu, zawartość części lotnych, zawartość wilgoci całkowitej oraz zawartość metali ciężkich ( $\mathrm{Cd}, \mathrm{Tl}, \mathrm{Hg}, \mathrm{Sb}, \mathrm{As}, \mathrm{Pb}$, $\mathrm{Cr}, \mathrm{Co}, \mathrm{Cu}, \mathrm{Mn}, \mathrm{Ni}, \mathrm{W}$ ) i siarki. Badania wstępne pokazały, że w wyniku mieszania mułów węglowych z pyłem węglowym z węgla brunatnego, a następnie ich granulowania, istnieje możliwość powstania produktu o odpowiednich parametrach jakościowych i fizycznych, atrakcyjnych dla energetyki zawodowej. W porównaniu do samych mułów węglowych, granulaty sporządzone z mułu i pyłu węglowego z węgla brunatnego $\mathrm{z}$ dodatkiem zmielonego dolomitu lub bez, charakteryzują się wzrostem zawartości siarki do $1-1,4 \%$ Jest to nadal zawartość akceptowalna dla paliwa stałego w niektórych przypadkach w energety- 
ce zawodowej. W odniesieniu do próbki podstawowej mułu węglowego obserwowany wzrost zawartości poszczególnych składników toksycznych w próbkach mieszanek jest niewielki i można stwierdzić, że dodatek pyłu węglowego $\mathrm{z}$ węgla brunatnego czy węglanów nie ma znaczącego wpływu na całkowitą zawartość poszczególnych pierwiastków. Parametrem decydującym o przydatności w energetyce zawodowej jest wartość opałowa. Wielkość tego parametru dla mułów węglowych w stanie roboczym mieści się w granicach 9,4-10,6 MJ/kg. W przypadku przygotowanych mieszanin mułu węglowego z pyłami z węgla brunatnego wartość opałowa zdecydowanie wzrasta do wartości 14,0-14,5 MJ/kg (w stanie roboczym). Takie wartości zwiększają możliwości zastosowania w energetyce zawodowej i spełniają w szerszym zakresie wymagania stawiane dla jakości paliw stałych. Obserwuje się nieznaczne obniżenie wartości opałowej w przypadku granulowania $\mathrm{z}$ dodatkiem $\mathrm{CaO}$ lub węglanów. Biorąc pod uwagę analizowane parametry można stwierdzić, że przygotowane mieszanki mogą znaleźć zastosowanie w instalacjach do spalania paliw stałych z odsiarczaniem spalin o nominalnej mocy cieplnej nie mniejszej niż $1 \mathrm{MW}$. Na tym etapie pracy nie prowadzono analizy kosztowej przedsięwzięcia.

SŁOWA KLUCZOWE: górnictwo węgla kamiennego, muły węglowe, pyły węglowe z węgla brunatnego, granulowanie, parametry jakościowe, wartość opałowa, energetyka zawodowa 